\title{
MINERALOGY OF SODIUM METASOMATITES OF THE PERVOMAYSKE DEPOSIT AND THEIR INFLUENCE ON QUALITY OF IRON ORE CONCENTRATE
}

\begin{abstract}
(Рекомендовано членом редакційної колегії д-ром геол. наук О.В. Дубиною)
Nowadays, the exploitation of the Pervomayske deposit is in the northern direction. The large metasomatic bodies of ferruginous quartzites are manifested in the productive strata in the northern part of deposit. The metasomatic bodies of ferruginous quartzites influence technological parameters of the iron ore concentrate.This situation determines the purpose of this investigation. The mineral composition, genesis and technological parameters of riebeckite ferruginous quartzites of the Pervomayske deposit productive strata are studied.

The metasomatically changed ferruginous quartzites and features of their mineralogical zoning are examined mineralogically. The zones of riebeckitization are substracted within the boundaries of metasomatic bodies. The mineral composition, the structural and texture of riebeckite ferruginous quartzites are studied. The technological research for enrichment of riebeckite ferruginous quartzites is conducted.

Results of the mineral composition, the structure and the texture investigation, conditions of genesis of riebeckite ferruginous quartzites of riebeckite ferruginous quartzites are given. Generalized regularities in changing of ore technological parameters (iron content in concentrate composition, concentrate ratio, iron recovery in the concentrate, iron losses in mine tailings) in the metasomatic bodies section of deposit's productive strata are presented. The authors studied the influence of sodium metasomatism on technological parameters of riebeckite ferruginous quartzites
\end{abstract}

The results of mineralogical and technological studies of authors have been used as the basis for compiling mineralogical and technological maps for the deposit that are utilized for operation and future mining, for elaborating schemes of optimal iron ores blending before conveying them to concentration plants with the purpose of increasing the iron ore concentrate quality and decreasing iron losses in concentration wastes.

Originality consists in detailed carrying out of mineralogical research of riebeckite ferruginous quartzites of the Pervomayske deposit. Further, these results are used in technological tests for enrichment of riebeckite ferruginous quartzites.

It is necessary to take into consideration the obtained regularities of the variability for the technological parameters while specificating the mineralogical and technological ores classification and the mineralogical and technological mapping of the Pervomayske deposit.

Keywords:Ukranian Shield, Kryvyi Rih basin, Pervomayske deposit, ferruginous-siliceous formation, ferruginous quartzites, metasomatic changes, zone of riebeckitezation, dressability.

Introduction. Within the boundaries of ferruginoussiliceous formation in the Kryvyi Rih basin the sodium metasomatites are widely developed. Most intensively they occur in the northern part of the basin at the intersection of two deep-seated faults-Kryvyi Rih-Kremenchuk and Devladove.To the north and south from the Devladove fault zone sodium metasomatites in ores of the Kryvyi Rih series sharply decrease.

The Pervomayske deposit is located within the boundaries of the North iron ore district of the Kryvyi Rih basin. The productive strata of the deposit is composed of the fifth and sixth iron horizons of the Saksagan series. Such geological processes as sedimentagenesis, dynamothemal metamorphism, sodium metasomatism and hypergenesis took part in the formation of the productive strata. Influence of hypergenesis on the quality and ore concentration is negligible. It is connected with the conducting of mining operations at the level of hypsometric horizons in the opencast which are located much lower than the crust of weathering of ferruginous-siliceous formation.

It is difficult to assess the direct influence of sedimentation on ore enrichment, because iron ore sedimentary formations were exposed to dynamothermal metamorphism. As a result their mineral composition, structural and textural features, physical properties have been changed. Main characteristics of the mineralogical and chemical zoning of iron and shale horizons of the Saksagan series are preserved in the metamorphism process.

So, modern condition of magnetite quartzites of the Pervomayske deposit productive strata is due to the manifestation of dynamothermal metamorphism, sodium metasomatism and tectonogenesis. This is confirmed by the presence of about 50 routine mineral varieties of iron ore [19]. The latter are united in essential and accessory mineral varieties. The percentage of unchanged iron quartzites is about $40 \%$, riebeckitezated ones is about $44 \%$, catalysed ones is about $10 \%$, aegirinized, silicified and other varieties are up to $1 \%$ of the productive strata of total volume.

Such diversity of varieties of magnetite quartzites leads to variability of technological parameters of iron ore concentrate. Ores product of enrichment plant (iron content in concentrate composition) is changing between 62-63 wt.\% and 67-68 wt.\%. So,the main problem of technological stabilization process is solved by identifying of technological parameters' correlation of iron ore concentrate from iron ores composition.

As stated above, the volume of the Pervomayske deposit productive strata comprises riebeckite magnetite quartzites. It is constantly observed in the form of lens-like bodies in the quarry wall (fig. 1). Thickness of these bodies reaches 100 150 meters. In this connection, the authors of the article decided to study mineralogical and chemical composition, structural and texture of riebeckite metasomatites, and their influence on technological parameters of ironores.

Research analysis. During the $50^{\text {th }}-70^{\text {th }}$ years of the $20^{\text {th }}$ century sodium metasomatites were the object of active examination of many researchers. They considered the issues of geological positions, mineralogical and chemical composition, structure and texture, metallogenic specialization of metasomatic bodies. [1, 3-5, 8-10, 16-18]. Previous researches $[5,7,11,13]$ proved that genesis of metasomatism had been occurring at an interval 200-400 myr after completion of dynamothermal metamorphism of ferruginous-siliceous sediments (age of rocks, respectively, $1,8 \pm 0,05$ i $2,2 \pm 0,05 \mathrm{Ga}$ ). This particularly caused genesis of metasomatic bodies within the boundaries of iron ore series. These bodies influence technological parameters of ferrous ores of the Pervomayske deposit ofthe Northern Iron Ore Enrichment Works of Kryvyi Rih basin. [14, 15]. 


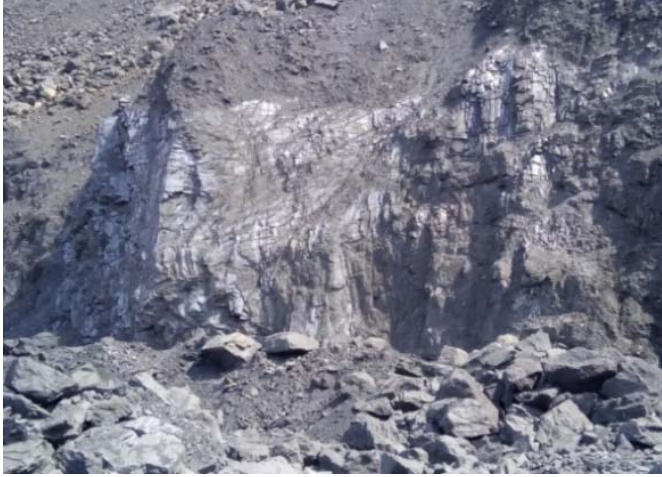

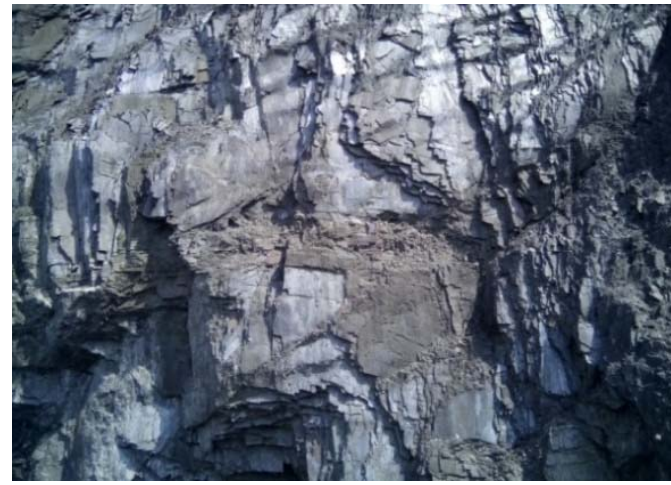

b

Fig. 1. Outcropping of riebeckite ferruginous quartzites in open-pit side of the Pervomayske deposit

Sodium metasomatism accompanied by aegirinezation, riebeckitezation of ferruginous quartzites and albitization of clay shales $[5,6,12,13,15,21]$. There are several opinions on the metasomatite genesis. According to some of them, sodium metasomatites originated as a result, of dynamothermal metamorphism of sodicferruginoussiliceous sediments. These sediments were similar to the sediments from the modern volcanic lakes of the East African rift. [22, 23]. Correspondingly to $[2,5,7,18]$ it is believed that in the iron ore strata metasomatic minerals are connected with metasomatizing effect of carbon dioxide sodium hydrothermal fluids on the protogene ferruginous quartzites. The third point of view is based on an assumption of convergency genesis of sodium amphiboles $[5,23]$ and possibility of metasomatites genesis as a result, of metamorphic, hydrothermal and metasomatic processes.

Most intensively sodium metasomatites occurred within the boundaries of productive strata of the Pervomayske deposit. In smaller quantity they occur within the boundaries of enclosing rocks $[15,21]$. Riebeckite, aegirine, albitite and others are metasomatically formed minerals. They are rock-forming minerals of many kinds of metasomatic ferruginous quartzites.

Mineralogical and technological features of ore of ferruginous-siliceous association including Pervomayske deposit were examined by B.I. Pirogov et al. [20]. Authors demonstrated the existence of direct dependence between concentrate quality $(\beta)$ and magnetite morphology and anatomy. They also proved a weaker bond of this technological parameter with general content of iron in ore composition (Fetotal.) and iron content in magnetite (Femagn.). It was sustained that the direct dependence between concentrate ratio $(\mathrm{V})$, iron recovery in the concentrate $(\varepsilon)$ and content ofFe $e_{\text {total. }}$ AndFe magn.in ore composition exists. It was determined that there was no dependence between content ofFetotal., $F_{\text {magn.in }}$ ore composition and iron losses in mine tailings $(\vartheta)$.

Practical experience of the Northern Iron Ore Enrichment Works shows that technological parameters of magnetite ores of the Pervomayske deposit are characterized by the considerable instability. This is explained with the occurrence of authigenicmetamorphogenic zoning of ore strata, natural ore breaking in zones of faulting and metasomatic changes.

Objective of research.Nowadays, the exploitation of the Pervomayske deposit is in the northern direction. The large metasomatic bodies of ferruginous quartzites occur in the productive strata in the northern part of deposit.

The metasomatic bodies are characterized by metasomatic zoning [4, 16, 21, 23] within the boundaries of protogenic mica-hematite-magnetite, magnetite and cummingtonite-magnetite-quartzites. In peripheral part of the productive strata the magnetite-cummingtonite quartzites rarely underwent metasomatic changes. This fact determines widening of mineralogical classification of iron ores. Generally mineralogical zoning is characterized by changing of metasomatic mineral zones (from the central to the peripheral part of metasomatic body): zone of aegirinezation $\rightarrow$ zone of riebeckitezation $\rightarrow$ zone of silification $\rightarrow$ zone of carbonatization $\rightarrow$ uninvaded zone of ferruginous quartzites $[4,5,12,15]$. Mineralogical zoning is based on significant changing content of rock-forming minerals and chemical components in mineralogical zones. The objective of this research is the determination of the regularities in mineral and chemical composition of metasomatically altered rocks depending on the intensity of metasomatic processes. As a result, the influence of sodium metasomatism on technological parameters of ferruginous quartzites'metasomatic varieties was studied. In condition of metasomatic changes of ferruginous-siliceous formation rocks the metasomatic zoning is superimposed on protogenicauthigenic-metamorphogenic zoning.The metasomatic zoning succeeds features of protogenicauthigenic-metamorphogenic zoning. As a result, these polygenic (sedimentation + metamorphism + metasomatism) bodies are complex in structure and variable in mineral and chemical composition within the boundaries of metasomatic zones.

The quantity of sodium (riebeckite) metasomatites exceeds $90 \%$ of the total volume of metasomatites in the Pervomayske deposit. In connection with this, the mineralogical composition, structure and texture of riebeckite varieties of ferruginous quartzites and variability of their technological parameters are considered below.

Laying out the main material. Ferruginous quartzites, which are specific in composition, structure and texture, are referred to sodium metasomatites. They are composed of such rock-formed minerals as aegirine, riebeckite (rhodusite) and albite. The affluent minerals include tetraferrous biotite, celadonite, apatite, zircon and other minerals. Sodium metasomatic bodies are characterized by the variety of forms and sizes. Veins, mineralization zones of crumpling and brecciation are the most common forms. The large lensoid bodies have the thickness of 100-150 meters and the length of 500-700 meters (rarely to 2000 meters).

When the Pervomayske deposit researched topomineralogically it was defined that mineralogical zoning is the characteristic feature of the metasomatic bodies. It is found in the maximum in thick strata. Within the boundaries of productive strata the mineralogical zoning is characterized by above mentioned metasomatic mineral zones. This zoning is poorly developed or absent in small metasomatic zones and zones of crush. In shales of the 
third-fifth horizon, the veins and lensoid bodies of sodium metasomatites are found in close spatial connection with the thick zones of desalination of the ferruginous quartzites. The third-fifth horizon interlays productive strata.

Zone of aegirinezation is zone of maximum metasomatic reconversion of ferruginous quartzites. If disregard the late-magmatic and postmagmatic minerals (carbonites, quartz, hematite, riebeckite and other) the composition of aegirinitemetasomatites is bimineral (aegirine + magnetite). Magnetite is relic. Mineral composition of aegirinites does not depend on content of protogenic ferruginous quartzites. Scaly texture of protogenic ferruginous quartzites is succeeded with aegirinite metasomatites. But the thickness of ore and nonore interbeds decreases due to the removal of silica and metasomatic compression. The thickness of aegirinezation zone is changing from 10s centimeters to 20-30 meters. Some bodies are $70-100$ meters thick.

Zone of riebeckitezation is traced by the replacement of quartz, magnetite and hematite with riebeckite. Affluent minerals are tetraferrousbiotite, celadonite, carbonates, aegirine. Thickness of riebeckitezation zone is changing from

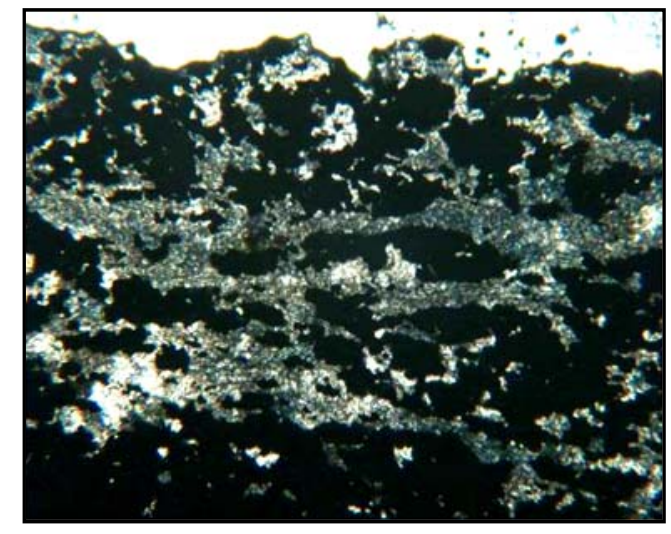

a tens centimetres to 4-50 meters, rarely 70 meters. Prolongation is $30-400$ meters. These zones were formed as a result of influence of the metasomatic dissolutions on the protogenicferruginous quartzites, and the increase of value of thermodynamic characteristics (sodium temperature activity, fugitivity of oxygen). It caused the greater dependence of mineralogical characteristics of riebeckitemetasomatites from the composition of protogenicferruginous quartzites. If riebeckitemetasomatites are formed by micaceous-hematitemagnetite and magnetite quartzites, the substantial part of the protogenic metamorphogenic micaceous-hematite and quartz has been preserved. In this case, riebeckite is close to the stoichiometric composition. Riebeckitezation of cummingtonite-magnetitequartzites occurred through pseudomorphosis of magnetite and magnesioriebeckite. According to the microscopic observations the neocrystallisation of the magnesioriebeckite is $1-20 \%$ of its total amount from the composition of metasomatites. Structurally and texturally, riebeckitemetasomatites retain the main features of protogenic ferruginous quartzites (fig. 2). In this connection they are called riebeckitemetasomatites or riebeckitevarieties of ferruginous quartzites.

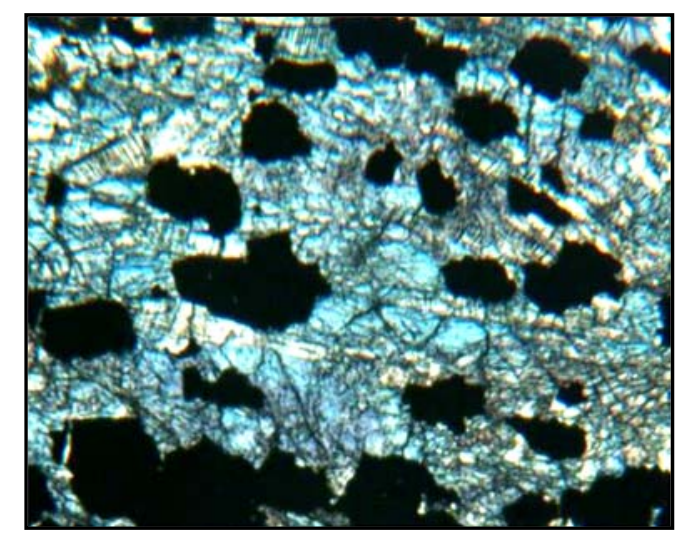

b

Fig. 2. Processes of riebeckitezation in ore (a) andno ore (b) interbeds of magnetite quartzites. Microscopic observations in translucent light.Nicol prism II. Zoom, In 50x. White - quartz; black - magnetite; blue - riebeckite; green - aegirine

Zone of silificationis characteristic for almost all metasomatic bodies. This zone is diagnosed by external signs. They show significant content of quartz, appearance of rich silification sections of enclosing rocks and presence of cross-cutting quartz veins. Ore and non ore interbeds of ferruginous quartzites are exposed to the processes of silification. As a result, the content of magnetite (in ore interbeds) and hematite (in non ore interbeds) is lower than their content in the unaltered ferruginous quartzites. In zone of silification affluent minerals are riebeckite, tetraferrousbiotite, celadonite, carbonates, rarely aegirine. Thickness of zone of silification is changing from 710 meters to $40-50$ meters.

Genesis of this zone was connected with "rundown" of silicon with metasomatic battery solutions. The "rundown" process took place from central metasomatic zones of riebeckitezation and aegirinezation to periphery of metasomatic bodies. Secondary ferruginous quartzites are characterized by complex morphology of magnetite individuals and aggregates (in the consequence of their partial replacement) and filling of protogenic ferruginous quartzites' grikes and vugs with secondary quartz.

The riebeckite varieties of ferruginous quartzites are widely developed within the boundaries of the fifth and sixth ferruginous horizons of the Pervomayske deposit. It is connected with the considerable thickness of the riebeckitization zone of metasomatic bodies.

The authors investigated 104 mineralogical samples of riebeckitemetasomatites in a face of the quarry of Pervomayske deposit. The mineral composition was identified in samples of the riebeckite metasomatites with a view to clarifying the existing data. The authors studied mineral composition on the base scientific and research mineralogical laboratory at the department of geology and applied mineralogy of Kryvyi Rih National University. Intermediate mineral composition of riebeckiteme tasomatites is shown in Table 1. 
Table 1. Intermediatemineral composition(vol.\%) of riebeckitemetasomatites

\begin{tabular}{|c|c|c|c|c|}
\hline \multirow[b]{2}{*}{ Minerals } & \multicolumn{4}{|c|}{ Riebeckitemetasomatites, which formed for such mineral varieties of ferruginous quartzites } \\
\hline & $\begin{array}{l}\text { micaceous-hematite- } \\
\text { magnetite quartzites }\end{array}$ & magnetitequartzites & $\begin{array}{c}\text { cummingtonite- } \\
\text { magnetite quartzites }\end{array}$ & $\begin{array}{c}\text { magnetite-cummingtonite } \\
\text { quartzites }\end{array}$ \\
\hline quartz & 23,74 & 24,48 & 24,34 & 26,76 \\
\hline magnetite & 25,94 & 33,14 & 28,70 & 17,44 \\
\hline micaceous-hematite & 5,05 & 0,95 & 0,25 & 0,16 \\
\hline cummingtonite & 0,00 & 0,04 & 1,77 & 4,15 \\
\hline biotute & 0,00 & 0,00 & 0,05 & 1,15 \\
\hline aegirine & 0,54 & 0,41 & 0,30 & 0,17 \\
\hline $\begin{array}{c}\text { riebeckite, } \\
\text { magnesioriebeckit }\end{array}$ & 41,78 & 37,79 & 41,31 & 46,54 \\
\hline albite & 0,00 & 0,00 & 0,00 & 0,06 \\
\hline tetraferrousbiotite & 0,39 & 0,34 & 0,11 & 0,07 \\
\hline celadonite & 0,44 & 0,42 & 0,28 & 0,22 \\
\hline ferruginous talcum & 0,12 & 0,08 & 0,06 & 0,06 \\
\hline carbonates $^{1}$ & 1,15 & 1,28 & 1,44 & 1,55 \\
\hline sulfides $^{2}$ & 0,19 & 0,22 & 0,27 & 0,29 \\
\hline apatite & 0,12 & 0,15 & 0,18 & 0,21 \\
\hline other minerals ${ }^{3}$ & 0,54 & 0,70 & 0,94 & 1,17 \\
\hline Total & 100,00 & 100,00 & 100,00 & 100,00 \\
\hline Quantity of definitions & 26 & 27 & 25 & 26 \\
\hline
\end{tabular}

${ }^{1}$ Carbonates: calcite, dolomite, ferodolomite, reralysideroplesite, pistomessite.

${ }^{2}$ Sulphides: pyrite, pyrotine, chalcopyrite, arsenopyrite, marcasite.

${ }^{3}$ Other minerals: chlorite, garnet, stilpnomelane, tourmaline, zircon.

According to the results of the mineralogical studies the authors discovered that the largest content of riebeckite $(46,54 \mathrm{vol}$. \%) was characterized for riebeckitization zones of metasomatites, which were originated from magnetitecummingtonite quartzites. This phenomenon is due to a significant content of silicates (cummingtonite) in protogenic ferruginous quartzites. Sodium amphibole (riebeckite) displaced cummingtonite in the process of metasomatism.

The content of the commercial component (magnetite) is slightly changed. In micaceous-hematite-magnetitequartzites the content of magnetite is $29,96 \mathrm{vol}$. \%, averagely. In the riebeckite varieties of the micaceous-hematite-magnetite quartzites the content of magnetite is $25,94 \mathrm{vol}$. \%. It is $4 \%$ different. The same situation is observed in othervarieties of ferruginous quartzites and their metasomatitic bodies in the deposit. The content of quartz decreased more than twice. It makes easier the enrichment process of the mentioned ores. To prove that the authors have carried out technological research to select the methods of riebeckite ferruginous quartzites enrichment of the Pervomayske deposit. Technological testing were carried out scientific and research mineralogical laboratory at the department of geology and applied mineralogy of Kryvy iRih National University. The obtained data are given in the Table 2.

Table 2. Technological parameters of riebeckitemetasomatites of ferruginous quartzites

\begin{tabular}{|l|c|c|c|c|c|c|}
\hline \multirow{2}{*}{ Varieties offerruginous quartzites } & \multicolumn{3}{c|}{ Chemicalparameters, \% } & \multicolumn{3}{c|}{ Technological parameters, \% } \\
\cline { 2 - 7 } & $\mathrm{Fe} \mathrm{e}_{\text {total. }}$ & $\mathrm{Fe}$ magn. & $\beta$ & $\gamma$ & $\varepsilon$ & $\square$ \\
\hline Micaceous-hematite-riebeckite-magnetitequartzites & 40,6 & 26,7 & 67,7 & 46,2 & 76,1 & 20,5 \\
\hline Magnetite-riebeckite-quartzites & 40,8 & 33,8 & 68,8 & 49,1 & 83,4 & 11,7 \\
\hline Cummingtonite-magnetite-riebeckitequartzites & 33,4 & 26,0 & 68,5 & 40,7 & 81,8 & 9,6 \\
\hline
\end{tabular}

It was established that the quality of magnetite concentrate obtained from riebeckite varieties is high and stable $(\beta=68-69$ mass. $\%$ ) depending on the protogenic magnetite quartzites of the deposit (Table 2). This is due to relatively weak displacement of magnetite (ore mineral) by riebeckite in comparison to other zones of metasomatic bodies (zone of aegirinezation and silification). In addition, moderate metasomatic changes contributed the first displacementof disseminated magnetite by riebeckite and simplification of the form of large individuals and aggregates of magnetite. Possibly, this improves the release of magnetite during ore crushing and also promotes improvement of recovery of magnetite in the concentrate and low losses of magnetite in mine tailings.

Concentrate ratio $(\mathrm{Y})$ and iron recovery in the concentrate $(\varepsilon)$ are monitored with the content of magnetite in ore composition and proportion of magnetite and other ironbearing minerals (micaceous-hematite, cummingtonite). The highest technological parameters (concentrate ratio $49,1 \%$, iron recovery in the concentrate $83,4 \%$ ) are characterized for riebeckitemetasomatites, depending on the magnetite quartzites of the deposit. This is explained with the high content of magnetite in protogenic magnetite quartzites.
The values of general iron losses in the process of enrichment $(\vartheta)$ depend on the content of relic high-ferrous nonmagnetite minerals (cummingtonite, micaceoushematite, and neogenicriebeckite and aegirine) in the ore composition. This parameter causes the character of variability for iron losses in the process of enrichment in the riebeckite varieties of ferruginous quartzites. This largest parameter is for micaceous-hematite-riebeckitemagnetitequartzites $(\vartheta=20,5 \%$ ) and the lowest one - for cummingtonite-magnetite-riebeckitequartzites.

In the previously published works of one of the authors, data were obtained on the enrichment of the aegyrinized and silicified varieties of ferruginous quartzites in the Northern Region of the Kryvyi Rig basin [15].Analyzing the obtained data, we can conclude that the technological parameters of riebeckite varieties of ferruginous quartzites $\beta=67,7-$ $68,8 \%$ ) are larger than the technological parameters of aegirine $(\beta=66,6 \%)$ and silificate $(\beta=61,8-66,4 \%)$ ferruginous quartzites.

Conclusions.1. Within the boundaries of the Pervomayske deposit productive strata the developed sodium metasomatism is imposed on the protogenic magnetite quartzites, thus forming the inhomogeneity of the mineral iron ore composition. 
2. Riebeckitezatingferruginous quartzites comprise the significant amount (about $44 \%$ of the total volume of productive strata) of mineral varieties of ferruginous quartzites. Mineralogical research showed a significant variation in compositionof riebeckite varieties of ferruginous quartzites. This phenomenon is due to superimposition of the metasomatic zoning on protogenicauthigenicmetamorphogenic zoning. The authors of article showed that the largest content of riebeckite $(46,54 \mathrm{vol}$. \%) is characterized for cummingtonite-magnetiteriebeckitequartzites. The obtained data specificate the mineral composition of riebeckitezating ferruginous quartzites, which were uncovered in the third ore body within the boundaries of the Pervomayske deposit.

3. During technological investigation it was defined that sodium metasomatism has different effects on the of technological parameters changing. The most positive effect is observed in riebeckitemetasomatites depending on originating from the protogenic micaceous-hematitemagnetite, magnetite and cummingtonite-magnetite quartzites. This is caused combinations of following factors: the improvement of ore morphological features, internal structure of individuals and aggregates of magnetite, the character of extensional interrelation of individuals and aggregates of magnetite and no ore minerals under the action of sodium metasomatism. The best technological parameters $(\beta$ and $\gamma)$ are characterized for magnetiteriebeckitequartzites. This is due to the proportion of magnetite and other minerals in protogenic magnetitequartzites.

4. It is necessary to take into consideration the obtained regularities of the variability for the technological parameters while specificating the mineralogical and technological ores classification and mineralogical and technological mapping of deposit.

\section{Список використаних джерел}

1. Белевцев Я.Н. О золотой минерализации в метасоматитах докембрия / Я.Н. Белевцев, И.И. Сахацкий, О.Ф. Макивчук // Геолог. журн. 1972. - T. 32, № 1. - С. 137-138.

2. Генезис железных руд Криворожского бассейна / Я.Н. Белевцев, Г.Г. Бура, Р.П. Дубинкина и др. - К. : Изд.-во АН УССР, 1959. - 308 с.

3. Евтехов В.Д. Особенности минералого-технологического картирования месторождений в метасоматически измененных железистых кварцитах (на примере Кривбасса) / В.Д. Евтехов // Онтогения минералов и технологическая минералогия. - К. : Наук. думка, 1988. - С. 82-92.

4. Евтехов В.Д. Основные закономерности локализации натриевых метасоматитов в железисто-кремнистых формациях докембрия / В.Д. Евтехов // Геолого-мінерал. вісн. Криворізького технічного ун-ту. 2000. - № 1-2. - С. 3-11.

5. Евтехов В.Д. Генетическая и прикладная минералогия натриевых метасоматитов железисто-кремнистых формаций Украинского щита (по природным и экспериментальным данным) : автореф. дис. ... д-ра. геол.минерал. наук: 04.00.20 / В.Д. Евтехов. - Л., 1992 - 40 с.

6. Евтехов В.Д. Об особенностях состава и свойств рибекитов Северного Криворожья / В.Д. Евтехов, Л.И. Полтавец // Докл. АН УССР. Сер. Б. -1980 . - № 5. - С. 13-15.

7. Елисеев Н.А. Метасоматиты Криворожского рудного бассейна / Н.А. Елисеев, А.П. Никольский, В.Г. Кушев // Тр. Лабор. геологии докебмрия АН СССР. - М.; Л. : Изд. АН СССР, 1961. - Вып. 13. - 204 с.

8. Железисто-кремнистые формации докембрия Европейской части СССР. Структуры месторождений и рудных районов / Я.Н. Белевцев, А.В. Вайло, В.В. Ветренников и др. - К. : Наук. думка, 1989. - 156 с.

9. Железисто-кремнистые формации докембрия Европейской части СССР. Минералогия / Б.И. Пирогов, Ю.М. Стебновская, В.Д. Евтехов и др. - К. : Наук. думка, 1989. - 168 с.

10. Железисто-кремнистые формации докембрия Европейской части СССР. Метаморфизм / Р.Я. Белевцев, О.Я. Беляев, В.В. Ветреницков и др. - К. : Наук. думка, 1989. - 148 с.

11. Занкевич Б.А. О структурной позиции щелочных метасоматитов Первомайского железорудного месторождения Кривбасса / Б.А. Занкевич, В.Д. Евтехов, Д.Н. Кондратьева // Роль структурных и структурногеохимических факторов в рудообразовании. - К. : Изд-во ИГФМ АН УССР, 1980. - С. 21-24.

12. Зарайский Г.П. Зональность и условия образования метасоматических пород / Г.П. Зарайский. - М. : Наука, 1989. - 344 с.

13. Зональность натриевых метасоматитов в железистых кварцитах Северного Криворожья / В.Д. Евтехов, Г.П. Зарайский, В.Н. Балашов, О.К. Валеев // Очерки физико-химической петрологии. - М. : Наука, 1988. - № $15 .-$ C. $17-37$.
14. Карпенко С.В. Топомінералогія залізисто-кременистої формації Ганнівського родовища Криворізького басейну : автореф. дис. ... канд. геол.-минерал. наук: 04.00.20 / С.В. Карпенко. - К., 2011. - 22 с.

15. Карпенко С.В. Влияние минералогической зональности продуктивной толщи Анновского месторождения на обогатимость руд / С.В. Карпенко // Пробл. недроиспользования: междунар. форум-конкурс. - СПб., 2010. - С. 34-36.

16. Карпенко С.В. Генетические разновидности рибекита Анновского месторождения Криворожского бассейна / С.В. Карпенко, В.Д. Евтехов // Геолого-мінерал. вісн. - 2008. - № 2 (20). - С. 33-41.

17. Коржинский Д.С. Очерк метасоматических процессов / Д.С. Коржинский // Основные проблемы в учении о магматогенных рудных месторождениях: - М. : Изд-во АН СССР. - 1955. - С. 335-456.

18. Куман В.Е. Геохимические и минералого-петрографические данные натрового метасоматоза в докембрийских железисто-кремнистых формациях (на примере Криворожья) / В.Е.Куман // Контроль и технология процессов обогащения полезных ископаемых. - М. : Недра, 1971. Вып. 1. - С. 126-135

19. Минералогическое изучение руд Первомайского месторождения Северного ГОКа с определением технологических показателей выделенных разновидностей руд и оконтуривание залежей руд с разными показателями обогащения / В.Д. Евтехов, Т.А. Олейник, Е.В. Евтехов и др. - НИР № 711 / 17-927-12. - КНУ, 2013. - 120 c.

20. Минералого-технологическое картирование железорудных месторождений Северного Криворожья / Б.И. Пирогов, В.Д. Евтехов, Д.Н. Кондратьева, Е.М. Романюк, П.Н. Хартанович, Л.И. Полтавец // Горный журн. - 1980. - № 10. - С. 12-15

21. Половинкина Ю.И. Натровый метасоматоз как закономерность в образовании месторождений железистых кварцитов / Ю.И. Половинкина // Зап. Всесоюз. минерал. об-ва. - 1949. - 78, № 1. - С. 52-58.

22. Скаржинский В.И. О некоторых особенностях условий образования щелочных амфиболов в центральной части Криворожского бассейна / В.И. Скаржинский // Зап. Всесоюз. минерал. об-ва. - 1958. - 87, № 2. - C. 230-233.

23. Стрыгин А.И. Метасоматоз в железорудных толщах украинского докембрия / А.И. Стрыгин, Л.Р. Казаков, В.А. Белоус // Геолог. журн. 1988. - № 6. - C. 25-33.

Reference

1. Belevtzev, Ya.N., Sahatzkiy, I.I., Makivchuk, O.F. (1972). About gold mineralization in metasomatites of Precambrian. Geological journal, 32, 1 , 137-138. [In Ukranian].

2.Belevtzev, Ya.N., Bura, G.G., Dubinkina, R.P. et al. (1959). Genesis of ferrous ore in Kryvyi Rih basin. Kyiv: ANUSSR, 308 p. [In Ukranian].

3. Evtekhov, V.D. (1988). Features of the mineralogical and technological mapping of deposit in metasomatic changes ferruginous quartzites(for example of Krivbas). Ontogeny of minerals and technological mineralogy. Kyev: Naukova dumka, 82-92. [In Ukranian].

4. Evtekhov, V.D. (2000). The main regularities of sodium metasomatiteslocalization in the ferruginous-siliceous formations of the Precambrian. Geological and Mineralogical Journal of Kryvyi Rih Technical University, 1-2, 3-11. [In Ukranian].

5. Evtekhov, V.D. (1992). Genetic and applied mineralogy of sodium metasomatites in the ferruginous-siliceous formations of the Ukrainian shield (according to natural and experimental data).Extended abstract of Doctor's thesis (Mineralogy, Crystallography). Kyiv,Vernadsky Nation Library of Ukraine, 40 p. [InUkranian].

6. Evtekhov, V.D., Poltavets, L.I. (1980). On the features of the composition and properties of riebeckites in the North Kryvyi Rih. Reports of the Academy of Sciences of the Ukrainian SSR. Series B, 5, 13-15. [InUkranian].

7. Eliseev, N.A., Nikolsky, A.P., Kushev, V.G. (1961). Metasomatites of the Kryvyi Rig Ore Basin. Proceedings of the Laboratory of Precambrian Geology of the USSR Academy of Sciences. Moscow-Leningrad: Publ. of Academy of Sciences of the USSR, 13, 204 p. [In Russian]

8. Belevtsev, J.N., Vailo, A.V., Vetrennikov, V.V. et al. (1989). The ferruginous-siliceous formations of the Precambrian in the European part of the USSR. Structures of deposits and ore regions. Kiev: Naukova Dumka, 156 p. [In Ukranian].

9. Pirogov, B.I., Stebnovskay, U.M., Evtekhov, V.D. et al. (1989). The ferruginous-siliceous formations of the Precambrian in the European part of the USSR. Mineralogy. Kiev: Naukova dumka, 168 p. [In Ukranian].

10. Belevtsev, R.Ya., Belyaev, O.Ya., Vetrennikov, V.V. (1989). The ferruginous-siliceous formations of the Precambrian in the European part of the USSR. Metamorphism. Kiev: Naukova dumka, 148 p. [In Ukranian].

11. Zankevich, B.A., Evtekhov, V.D., Kondratieva,D.N. (1980). On the structural position of sodium metasomatites in the Pervomayske iron ore deposit of Kryvbas. The role of structural and structural-geochemical factors in ore formation. Kiev: IGFM AN UkSSR, 21-24. [InUkranian].

12. Zarayskiy, G.P. (1989). Zoning and formation conditions of metasomatic rocks. Moskow: Nauka, 344 p. [in Russian]

13. Evtekhov, V.D. Zaraysky, G.P., Balashov, V.N., Valeev, O.K. (1988). Zoning of sodium metasomatites in ferruginous quartzites in the Northern Kryvyi Rih. Essays on physic and chemical petrology. Moscow: Nauka, 15, 17-37. [In Russian]

14. Karpenko, S.V. (2011). Topomineralogy of Hannivka deposit ferriferous-flinty formation at Kryvyi Rih basin. Extended abstract of PhD thesis (Mineralogy, Crystallography). Kyiv: Vernadsky Nation Library of Ukraine, 22 p. [In Ukranian]. 
15. Karpenko, S.V. (2010). Influence of mineralogical zoning of the Annovskoye deposit productive strata on the ore enrichment. Problems of subsoil use: international forum-competition. St. Petersburg, 34-36. [In Russian].

16. Karpenko, S.V., Evtekhov, V.D. (2008). Genetic varieties of riebeckite in the Annovskoye deposit of the Krivoy Rog basin. Geological and Mineralogical Journal, 2 (20), 33-41. [InUkranian].

17. Korzhinsky, D.S. (1955). Essay on metasomatic processes. Basic problems in the theory of magmatogenic ore deposits. Moskow: AN USSR, 335-456. [In Russian]

18. Kuman, V.E. (1971). Geochemical and mineralogical-petrographic data of sodium metasomatism in Precambrian ferruginous-siliceous formations (by the example of Krivorozhye). Control and technology of enrichment process. Moscow: Nedra, 1, 126-135. [In Russian]

19. Evtekhov,V.D., Oleynik, T.A., Evtekhov, E.V.(2013). Mineralogical study of the Pervomayske deposit ore of the North Mining Ore enrichment Combine with finding of technological parameters of substract varieties ore and delination ore delf with different parameters of enrichment. № 711 / 17927-12. KNU, 120 p. [In Ukranian].

20. Pirogov, B.I., Evtekhov, V.D., Kondratieva, D.N., Romanyuk, E.M., Khartanovich, P.N., Poltavets, L.I. (1980). Mineralogical and technological mapping of iron ore deposits in the North Krivoy Rog region. Mining Journal, 10, 12-15. [In Russian].

21. Polovinkina, Yu.Ir. (1949). Sodium metasomatism as a regularity in the formation of ferruginous quartzites deposits. Russian Mineralogical Society, 78, 1, 52-58. [InRussian]

22. Skarzhynsky, V.I. (1958). On some features of the conditions for the formation of sodium amphiboles in the central part of the Krivoy Rog basin. Russian Mineralogical Society, 87, 2, 230-233. [InUkranian].

23. Strygin, A.I., Kazakov, L.R., Belous, V.A. (1988). Metasomatism in the iron ore strata in the Ukrainian Precambrian. Geological Journal, 6, 2533. [InUkranian].

Надійшла до редколегії 11.10.17

С. Тіхлівець, канд. геол. наук, старш. викладач

E-mail: tikhlivets.svetlana@gmail.com,

В. Філенко, старш. наук. співроб., зав. лаб.

E-mail: valentina.filenko@mail.ru

Криворізький національний університет

вул. Пушкіна, 37, м. Кривий Ріг, 50002, Україна

\section{МІНЕРАЛОГІЯ НАТРІЄВИХ МЕТАСОМАТИТІВ ПЕРВОМАЙСЬКОГО РОДОВИЩА ТА ЇХНІЙ ВПЛИВ НА ЯКІСТЬ ЗАЛІЗОРУДНОГО КОНЦЕНТРАТУ}

На сучасний момент розробка Первомайського кар'єра ведеться в північному напрямку. У цій частині родовища в межах продуктивної товщі спостерігаються крупні, метасоматично змінені тіла залізистих кварцитів, які значною мірою впливають на технологічні показники залізорудного концентрату. Саме це й обумовлює мету даної роботи - вивчення мінерального складу, структури та текстури, умов утворення рибекітових різновидів залізистих кварцитів Первомайського родовища, а також їхніх технологічних показників.

Мінералогічне дослідження метасоматично зміненних залізистих кварцитів та особливостей їхньої мінералогічної зональності виконувалось за стандартною методикою. Було виділено в межах метасоматичних тіл зони рибекітизації та вивчено їхній мінеральний та структурно-текстурний склад. Було проведено технологічні дослідження із збагачення рибекітових різновидів залізистих кварцитів.

У роботі наведено результати вивчення мінерального складу, структури та текстури рибекітових різновидів залізистих кварцитів, а також умов їхнього утворення. Проаналізовано узагальнені закономірності зміни основних технологічних параметрів руд (вміст заліза у складі концентрату, вихід концентрату, вилучення заліза до концентрату, втрати заліза у хвостах збагачення) у розрізі метасоматичних тіл продуктивної товщі родовища. Авторами було досліджено вплив натрієвого метасоматозу на технологічні показники рибекітових різновидів залізистих кварцитів.

Результати топомінералогічних і технологічних досліджень було використано як основу для розробки мінералогічної й технологічної карт родовища, що застовуються при оперативному і перспективному плануванні гірничодобувних робіт, складанні схем оптимального усереднення залізних руд перед подачею їх на збагачувальні фабрики з метою підвищення якості залізорудного концентрату $і$ зменшення втрат заліза у відходах збагачення.

Наукова новизна полягає в детальному проведенні мінералогічних досліджень рибекітизованих залізистих кварцитів продуктивної товщі Первомайського родовища. А також у подальшому використанні цих результатів у технологічних випробуваннях із збагачення рибекітизованих залізистих кварцитів.

Отримані закономірності мінливості технологічних показників метасоматично змінених руд у розрізі продуктивної товщі необхідно врахувати при уточненні мінерально-технологічної класифікації руд і при мінералого-технологічному картуванні родовища.

Ключові слова: Первомайське родовище, залізисто-кремениста формація, залізисті кварцити, метасоматичні зміни, зона рибекітизації, збагачувальність.

С. Тихливец, канд. геол. наук, ст. препод.

E-mail: tikhlivets.svetlana@gmail.com

В. Филенко, ст. науч. сотр., зав. лаб.

E-mail: valusha.geol@gmail.com

Криворожский национальный университет

ул. Пушкина, 37, г. Кривой Рог, 50002, Украина

\section{МИНЕРАЛОГИЯ НАТРИЕВЫХ МЕТАСОМАТИТОВ ПЕРВОМАЙСЬКОГО МЕСТОРОЖДЕНИЯ И ИХ ВЛИЯНИЕ НА КАЧЕСТВО ЖЕЛЕЗОРУДНОГО КОНЦЕНТРАТА}

На сегодняшний день разработка Первомайского карьера ведется в северном направлении. В этой части месторождения в пределах продуктивной толщи наблюдаются крупные метасоматически измененные тела железистых кварцитов, которые в значительной мере влияют на технологические показатели железорудного концентрата. Эта ситуация и обусловливает цель данной работы - изучение минерального состава, структуры и текстуры рибекитовых разновидностей железистых кварцитов Первомайского месторождения, условий их образования, а также технологических показателей.

Минералогические исследования метасоматически измененных железистых кварцитов и особенностей их минералогической зональности выполнялись по стандартной методике. Были выделены в пределах метасоматических тел зоны рибекитизации, изучен их минеральный, структурно-текстурный состав. Были проведены технологические исследования по обогащению рибекитовых разновидностей железистых кварцитов.

Приведены результаты изучения минерального состава, структуры и текстуры рибекитовых разновидностей железистых кварцитов, а также условий их образования. Проанализированы обобщенные закономерности изменений основных технологических параметров руд (содержание железа в составе концентрата, выход концентрата, извлечение железа в концентрат, потери железа в хвостах обогащения) в разрезе метасоматических тел продуктивной толщи месторождения. Авторы изучили влияние натриевого метасоматоза на технологические показатели рибекитовых разновидностей железистых кварцитов.

По результатам топоминералогических и технологических исследований были построены геолого-минералогическая и геолого-технологическая карты месторождения, которые используются при оперативном и перспективном планировании добычи руд, составлении схем их оптимального усреднения перед подачей на обогатительные фабрики, повышения качества железорудного концентрата, уменьшения потерь железа в отходах обогащения

Научная новизна состоит в детальном проведении минералогических исследований рибекитизированых железистых кварцитов продуктивной толщи Первомайского месторождения, а также в дальнейшем использовании этих результатов в технологических испытаниях по обогащению рибекитизированых железистых кварцитов.

Полученные закономерности вариативности технологических показателей метасоматически измененных руд в разрезе продуктивной толщи необходимо учитывать при уточнении минерально-технологической классификации руд и минералого-технологическом картировании месторождения.

Ключевые слова: Первомайское месторождение, железисто-кремнистая формация, железистые кварциты, метасоматические изменения, зона рибекитизации, обогатимость. 